\title{
PHILOSOPHY WITH CHILDREN AND EDUCATION FOR HUMAN RIGHTS - including workshop examples ${ }^{1}$
}

\author{
Bruno Ćurko \\ Faculty of Humanities and Social Sciences, University of Split \\ Zvjezdana Cah \\ Faculty of Humanities and Social Sciences, University of Split
}

\begin{abstract}
Philosophy with children officially begins with Matthew Lipman who initiated it in the 1970s. He was prompted to do so by the fact that his students struggled with critical thinking. This encouraged him to establish the Institute for the Advancement of Philosophy for Children at Montclair State University. Even though the movement has faced some criticism, it continues to spread around the world. The reason for this are the methods used, i.e. stories, games, conversations, questions, etc., as well as the topics analysed. Philosophy with children addresses numerous topics, while this paper will focus on human rights, more specifically, what human rights are, what the most important human rights are, and how they might be violated. In order to make this subject matter more accessible to children, at the end of the paper, an overview of two workshops is given, which may be applied to the subject of human rights in practicing philosophy with children.
\end{abstract}

Keywords: philosophy with children, Matthew Lipman, philosophy with children methodology, human rights, education, workshops examples

\section{INTRODUCTION}

In contemporary society, more than ever before, human beings have everything at their disposal: from products and services to information. However, in this mass of information daily presented by the media, humans struggle to discern the facts. One of the ways that can help humans in finding their bearings in today's world is to adopt a critical, i.e., reflexive mode of thinking. To an extent, it is possible to adopting a critical mode of thinking later on in life, but it is best to become accustomed to the skill of critical thinking since childhood. Matthew Lipman became aware of this when, about fifty years ago, he noticed that his students lacked a highly developed ability of critical thinking, which is why he initiated the philosophy with children and founded the Institute for the Advancement of Philosophy for Children at Montclair State University. Since then, the movement of "using your own head" since childhood has spread around the world and it is still a valid approach today. The aim of philosophy with children is not for them to learn certain ideas, but to acquire a methodology of critical thinking about a vast variety of topics they encounter in their daily lives, such as friendship, values, education, protection of the environment, and human or children's rights. The latter topic undoubtedly raises interest because it is one of the primary concerns of human beings in the present age. Even though it is not mentioned, discussed or contemplated much, it seems that

\footnotetext{
${ }^{1}$ This paper is the adapted and supplemented dissertation by Zvjezdana Cah, titled "Philosophy with children and education for human rights," defended at the Faculty of Humanities and Socials Sciences, University of Split, in September 2020.
} 
THEORETICAL AND PRACTICAL PROBLEMS AND DISCUSSIONS

TEORIJSKI I PRAKTIČNI PROBLEMI I RASPRAVE

we still have not reached the stage where respecting the rights of others is universally understood and they are still largely violated. That is why it is important to start contemplating human rights with children, whereas philosophy with children is an ideal "platform" for inculcating into younger generations the idea of respecting human rights.

\section{PHILOSOPHY WITH CHILDREN ${ }^{2}$}

Philosophy with Children is a branch of practical philosophy, which means that it is suitable for a vast number of people who need not be academically educated and that it has a great impact on human beings' daily life. The most widespread branches of practical philosophy are: Socratic dialogue, Philosophical counselling and the abovementioned Philosophy with Children.

Philosophy with children describes the practice by which philosophers, teachers and children together grasp the fundamental principles of philosophical thought. It is intended for children, inasmuch the modes of thinking are adapted to children's age and affect their daily lives. In philosophy with children, the teachers encourage children to express anxiety, questions, search for answers, etc. This young philosophical discipline also serves to express a preoccupation with the values that are important to everyone but sometimes seem abstract, insofar that they form an integral part of what humans are expected to believe, learn or value. Philosophy with children encourages the use of language in the process of contemplation, in order to increase clarity in speech and writing (Steve Williams, P4C: what, why and how?).

The founder of the movement that is nowadays widespread, M. Lipman, wrote philosophical novellas in order to make philosophical themes more accessible to youth and children. The young characters in his novellas asked the same sort of questions he wanted the students to ask once they became "philosophically sensitive" to their experience of life. The characters in the stories provide examples of searching for common answers to question that are important to children, but are in fact philosophically relevant. Lipman's novellas for children, combined with developed methodology, result in sharing opinions, considering the opinions of other participants, searching for specific answers, re-examining hypotheses, etc. The teachers, i.e., the facilitators are described as an important source of intellectual support and encouragement. Lipman hoped that the entire educational system would integrate these principles and be encouraging, respectful of the concerns of young people and efficient in strengthening critical thought. He wanted the stories to be "...a challenge to teachers as well as pupils. If both groups were to find them interesting, there would be discussions of the texts, in which both teachers and pupils would participate. Such discussions could revolve around different interpretations" (Lipman, 2008: 118).

The second important method of Lipman's philosophy with children is the "community of philosophical inquiry," a notion borrowed from American philosopher of pragmatism Charles Peirce. "Lipman wrote: what impressed itself upon me... was the practice implied by the phrase', that of participants (the model from Peirce being scientists) who 'operated under two sets of requirements, one being the requirements of inquiry itself and the other being the requirements of communal life"'(Williams, 2012: 286). That means that there is respect for other people, as well as an interest in re-examining individuals' ideas.

Philosophy with children is characterized by dialogue related to group thinking, while the concept of thought is related to the notion of human fallibility and the necessity of selfcorrection. The question is whether these assumptions refer only to children or whether they apply to adults involved in the project as well.

2 There are two terms in use. Philosophy for Children (P4C), which refers to the approach developed by Matthew Lipman, and Philosophy with Children (PWC), which refers to all the approaches, including Philosophy for Children. 
Philosophy with children is created in dialogue, and almost since its beginning, the abovementioned founder Matthew Lipman collaborated with his associate Ann Margaret Sharp, therefore, the first theoretical works on philosophy with children were written in coauthorship. Hence, it is possible to conclude that Philosophy with Children is a joint dialogical project. Lipman wrote his philosophical stories for children on his own, however, in writing manuals for adults participating in the project of philosophy with children, he again opted for teamwork and prepared them together with his colleagues. Even in Lipman's independent works, it is possible to discern the influence of contemporary philosophy on his thought, especially John Dewey's and Charles Peirce's philosophy of pragmatism (Šimenc, 2012).

Lipman's philosophy with children consists of at least four steps, which are: novellas for the pupils, manuals for the teachers, theoretical texts problematizing philosophy with children, and practical work with children. There are also collections of theoretical texts that analyse the background of Lipman's novellas, especially Harry and Pixie (extremely useful for teachers who have no formal philosophical background). In his 2008 book Philosophy for Children, Practitioner Handbook, he lists five steps of the method:

“...reading a philosophical story, asking questions and establishing a programme of the work, discussing the questions within the research community, self-evaluation practices, philosophical exercises and actions), while between the episodes, the moderator introduces one thought exercises and one guided philosophical discussion about an important concept, based on the blueprint of the discussion in the manual. Between chapters, the moderator guides the pupils through a non-dialogical philosophical activity" (Šimenc, 2012, p. 23).

The method is systematic, and follows the principles of the method established about fifty years ago, with the innovation of introducing non-dialogical activities.

\section{SOME OF THE METHODS EMPLOYED IN PHILOSOPHY WITH CHILDREN USE OF STORIES IN PHILOSOPHY WITH CHILDREN}

Given the fact that, since the earliest childhood, children encounter telling stories in the environment of the family, kindergarten or school, they are ideal tools because they allow the children to connect the content of the story with their everyday life. That is why stories are also ideal for classes/workshops of philosophy with children. Through stories, the children can make considerable advancements: e.g. relate to a philosophical topic, resolve any confusion about the topic, confirm their own insights and theories about particular content, relate to the characters from the stories, discover new insights, ask questions, become motivated and create their own story. Stories are used in philosophy, as well as in many other school subjects, and they can be integrated into any part of the class/workshop: at the beginning, as motivation and introduction to the topic, in the middle, as a specific template for problematizing a topic, and at the end, as a conclusion of the topic. In choosing the appropriate story, attention needs to be paid to the age, abilities and aptitudes of the participants, i.e. children. During the first two years of a baby's life, the children accept and understand picture books with no text and very short stories of a few words. During the age of three to four, they are able to comprehend picture books which include text and short, simple stories. From the age four to seven, they begin to show interest in fairy tales and poetry for children. From the age eight to ten, they show an increasing interest in realistic stories in which the main characters are children and animals, as well as poetry for children, for which their interest wanes in subsequent periods. From the age of ten to thirteen, they are attracted to exciting texts, such as adventure novels and short stories and poetry, while, after the age of thirteen, they show interest in travel writing and works that describe events in nature. When choosing a story, we should keep in 
mind that it needs to be connected to the topic we are analysing, because, we should not use stories that are unrelated to the topic and content we wish to realize. For example, in problematizing the topic of friendship, we are not going to use the story of the three sieves of Socrates. Once we have chosen the story in accordance with the age, abilities, aptitudes, content and topic, the next stage is asking motivating questions related to the story and the topic of the lesson, while each question is supplemented by follow-up questions, so that the children are able to reach a constructive conclusion on their own (Ćurko and Kragić 2008).

\section{USE OF GAMES IN PHILOSOPHY WITH CHILDREN}

It is possible to characterize human beings in different ways, however, one of the important human characteristics is their ability to play. A human being is, therefore, homo ludens - "a human being who plays, therefore, this philosophical stance observes culture in its entirety as a consequence of that sort of game of exploration and quest, characteristic only of humans, which, in the infinity of its possibilities, acquires its articulation in philosophy, science, arts, law, politics, customs" (Kutleša, 2012: 534). Humans maintain the ability to play throughout their lives, however, this trait is most pronounced during childhood. Playing occupies children's imagination, it directs their attention, encourages concentration, and, by playing, children can learn and relate to their environment. That is why pedagogical textbooks recommend playing as a legitimate pedagogical and educational tool. Philosophy with children is no exception, hence, it encourages playing during its workshops.

Some of the games used in the workshops of Petit Philosophy, a special branch of philosophy with children, are: word association games, riddles, acrostics, guessing notions, guess who? games, stories, questions, role playing, etc. In philosophy with children workshops, teachers around the world use games to motivate children, introduce topics and encourage critical thought ${ }^{3}$.

\section{THE PRINCIPLES OF WORKING WITHIN A COMMUNITY OF INQUIRY}

The reflexive teaching model enables education through which children find their intrinsic motivation for learning. It is based on a community of inquiry that attempts to solve problems through joint efforts. In a group of children, discussion may be encouraged by what philosophy for children terms stimulus. The stimuli are varied: a video, a story, an image, a pupil's reaction, etc. Regardless of the stimulus used, it needs to be intense enough to prompt the children to think. That is why John Dewey states that:

"Demand for the solution of a perplexity is the steadying Regulation and guiding factor in the entire process of reflection. Where there is no question of a problem to be solved or a difficulty to be surmounted, the course of suggestions flows on at random... But a question to be answered, an ambiguity to be resolved, sets up an end and holds the current of ideas to a definite channel. Every suggested conclusion is tested by its reference to this regulating end, by its pertinence to the problem in hand" (Dewey 1909: 14).

The task of every teacher is constantly to cause their pupils to be perplexed and encourage them to think, therefore, it is necessary to cause a sensation of intellectual discomfort. What the pupil has believed so far needs to be brought into question, while this is most efficient

3 More information about the different games used in philosophy with children is available on the following website: https://www.topsypage.com/blog/2019/1/31/p4c-games. 
if the re-examination arises spontaneously. The pupils' first reaction to the stimulus is usually an emotional one; they become scared, confused, angry, etc. Their initial emotional reaction is followed by a cognitive one. The pupils are ready to continue thinking about this reaction, which motivates them to further exploration and work. That is why working within a community of inquiry needs to be based on the following principles: debate should be the preferred method of work - in order to encourage everyone's participation in solving the common problem. In addition, the participants need to be able to express their ideas freely and discuss what they do not understand, while everything that occurs during the workshop becomes the subject of further research. The important factors to consider are that the participants/pupils should listen to each other, all the pupils need to participate in the work, yes/no answers should be given, the pupils should never learn the teacher's point of view, and, it is important to note that everything that occurs during the class/workshop is reality, not a simulation of reality (Jeremić, 2012).

\section{THE COMMUNITY OF PHILOSOPHICAL INQUIRY}

Community of philosophical inquiry is the concept that is necessarily related to philosophy for children.

"'Community of inquiry' is a concept introduced by Charles Sanders Peirce, and was originally restricted to the practitioners of scientific inquiry. M. Lipman (2003) expanded this concept by moving it into a broader setting - the classroom. He converted the classroom into a community of inquiry, in which 'students listen to one another with respect, build on one another's ideas, challenge one another to supply reasons for otherwise unsupported opinions, assist each other in drawing inferences from what has been said, and seek to identify one another's assumptions.' Furthermore, Lipman developed the concept of Community of philosophical inquiry, which has proved to be very functional in philosophy for children workshops. Today, this concept is used in several different schools of philosophy with children. However, it could be argued that the Community of inquiry is the original concept in philosophy for children. Since Lipman's early work of the 1960s, and the beginnings of the practical use of the method, the concept of Community of philosophical inquiry, the method itself has been improved in different schools, but of course, the essence has remained the same" (Ćurko, 2020, 481).

This method, in Lipman's sense, turns the teacher into one of the equals in the classroom. The teacher, together with the students, researches and helps them lead the discussion by means of arguments. The goal is not to reach a definition, but to think about a certain problem, concept or event.

\section{NOTION AND DEFINITION OF HUMAN RIGHTS ${ }^{4}$}

The philosophical debate about human rights is more than ever before present in our minds, especially the minds of politicians. One of the most common contemporary political definitions of human rights states that they are "those rights that belong to an individual or a group of individuals as a consequence of the fact that they are human beings" (Anđelić, 2008: 12). Some sociologists claim that the syntagm "human rights" needs to be divided into the subject and the object, while this needs to be done according to the criteria of human rights violations. Therefore, humans are the subject of this syntagm, i.e. those that need to be

4 Portion of the paper under the title Notion and history of human rights was initially published as part of the final paper by Zvjezdana Cah titled Ethics and human rights, Split, 2018. 
protected, yet they are also the ones breaching these same rights. Therefore, they are both the subject and the object, and actively participate in both. Therefore, it might be said that people need to be protected from themselves, i.e., that some people need protecting from other people. There are also the 'third parties' who mediate, i.e., protect some people from certain other people. However, how do we determine which of these people belong to which category, i.e., which people need to be protected and which need to be prevented from harassing others. This should be the task and the role of law, however, laws are not always on the side of those who are weaker and the legal system, in terms of objective laws of a given country, is not always fair (Hollós, 1989).

In contemporary world, it seems that what generations throughout history had dreamt about is coming true: equality and equal rights for all, regardless of nationality, religion or race. Human rights as we know them today first became interconnected with political reality during modernity, with the advent of the philosophy of natural law. The United States Declaration of Independence (1776) and the French Declaration of the Rights of Man and of the Citizen (1789) in their essence contain John Locke's theory of natural rights. All subsequent texts about human rights draw from the foundations established in these two documents. In discussing human rights, it is possible to delineate between "original" and "derivative" human rights. The original rights are individual rights, i.e., those that refer exclusively to an individual. These are the 'classical' rights, of freedom of religion, of thought and of ideas. Derivative rights mostly refer to political and social rights, such as the right to democratic self-determination, therefore, the ones that an individual can exercise only together with others. Therefore, it is possible to conclude that original rights are always based on the supra-positive notion of right, while derivative rights always presuppose a certain positive framework of state and society (Becker, 2009).

\section{CRITICISM OF THE NOTION OF HUMAN RIGHTS}

At first glance, human rights seem to be a noble and natural ideal that would be difficult to contradict. However, certain philosophical currents criticize human rights claiming that the entire concept is unclear with regard to content. Criticism is also directed at the founder of natural rights, John Locke, on the basis that the supra-positive postulates of unalienable rights are not clearly defined. He based the validity of human rights on God, however, not on a Christian God, but on the deistic image of God that was 'worshiped' by the philosophers of the age. If that deistic concept of God is superimposed onto today's relations and reality, contemporary humans, who view the world through the prism of technology find it to be theologically and religiously unconvincing (Becker, 2009).

The second criticism levelled at human rights is the problem of the concept of a person. When we refer to a person, we assume an individual who is a discrete, proper, and irreplaceable singularity. Here it is important to distinguish between an individual as a member of a group and an individual as a person. As a member of a group, an individual is always determined as one in a series, one that exist in relationships of superiority, subordination or equality with other individuals. An individual person is understood as the inner perspective of each individual, whereby everyone is regarded as an unrepeatable individual who is unmistakably marked by one's name. However, when we approach the concept of a person, we often place an inequality sign between being a person and being a human being, which is not completely correct. The notion of a human being refers to an infinite number of individual human 'specimens,' as well as to the specific determination comparable to the relationship genus - species (e.g. different nations: Croatians, Slovenes, Italians, etc.). The 'pure' notion of a person receives a different treatment. It cannot be reduced to any sub-species. Each person is a unique individual that cannot be duplicated (Becker, 2009). 
When we discuss humanity in the context of human rights, three notions of humanity often intermingle without much distinction. The first is the notion of humankind, in which an individual is one of many members of humankind. However, in the notion of humankind itself, defining a person is inconsequential, therefore, a human being may be disregarded in a personal context. The second notion of humanity is derived from scholastic cosmology and its teachings about the creation of the world. According to this philosophy, God created humanity as a species that would be the crowning achievement in the hierarchy of all living beings. The third notion of humanity relates to a philosophical notion of the Enlightenment, according to which humanity is a multitude of individuals who are perceived as persons. If we transfer these notional distinctions to the discussion about human rights, it is possible to ascertain that the broadest notion of humanity is not suitable for the topic of human rights, because it is impersonal and perceives a human only as a member of humankind. We are left with the other two notions of humanity. The first is a collective-personal notion, expressed by scholastic cosmology, while the individual-personal notion of humanity is expressed by philosophies of the Enlightenment. The scholastic notion would only be applicable in Christian constitutional societies, however, it would go against the right to religious freedom, because not human beings are Christians. In addition, an objection against this notion of humanity could be that it regards an individual as a specimen among other specimens who are equal, not as a distinctive and unique individual. Therefore, all arguments point to the fact that the preferred notion of humanity is the one derived from the philosophy of Enlightenment, because it is the only one that relates to persons as uniquely defined individuals who are the bearers of rights (Becker, 2009).

\section{HUMAN RIGHTS AND THE DEMOCRATIC ASPECT OF PHILOSOPHY WITH CHILDREN}

Observed globally, there are different issues that preoccupy contemporary human beings, while one such issue is that of human rights. Despite the fact that "adults" struggle with this issue, it is included in the upbringing of children only to a slight degree. Human rights are often violated, while news of these violations are presented via different means of communication, yet these issues are not quickly resolved. People are conscious of the need for greater involvement around such issues, however, they are also aware of their powerlessness with regards to resolving these problems. The causes of this may be found in unequal power relations within a particular society and in different parts of the world, in the degree of development of certain areas, the educational level of its inhabitants, and the citizens' unequal opportunities to participate in decision-making processes on certain issues. That is why, in democratic societies, it is vital to cultivate the abilities related to the model of humane development. The development of such abilities is indispensable in the context of a person's chances for fulfilment in terms of the enjoyment of human rights. The denial of an individual's opportunities for the development of human rights, leads to violations of human rights in different parts of the world. The development of human abilities in terms of transforming human resources into abilities is also vital, as it increases one's participation in economic, personal and societal development. An unequal distribution of resources leads to serious violations of human rights, since poverty precludes the possibility of adequate education and prevents the use of all of one's abilities for the improvement of one's quality of life. This leads to structural breaches and violations of human rights. The denial of one right consequently leads to the denial of another right, whereas people who possess less power and resources remain permanently exposed to the violations of their rights. Even though different documents exist that guarantee the protection of civil, political, economic, social and other rights, the situation in practise is considerably different. Upholding human rights is an important criterion 
THEORETICAL AND PRACTICAL PROBLEMS AND DISCUSSIONS

TEORIJSKI I PRAKTIČNI PROBLEMI I RASPRAVE

of democratic societies, therefore, their protection should be an integral part of the fight for the rule of law (Radovan Burja, 2017).

Given the fact that philosophy with children is a practical philosophy, which means it attempts to integrate philosophy into daily life and apply it to the problems troubling all human beings, this also offers its legitimation to discuss human rights, and to do so with its practitioners - the children. A trait of this philosophy is that participants are expected to contribute to the dialogue by establishing connections with other participants. They do so by either agreeing or disagreeing with what they hear, after which they present arguments supporting their agreement or disagreement. The general rule is that no contribution to the discussion is more valuable than the other, but rather, that the participants collaborate in solving the problem together. Since this philosophy wishes to translate philosophical thought into everyday life, reflexion should not be a discrete and concealed activity, but rather, it should be articulated in parallel to an individual's life and the way this individual integrates into life. Philosophy with children not only develops cognitive and meta-cognitive activities, but it also fosters affective activities. Despite the fact that thinking and reasoning are vital for the promotion of human rights, the affective components should not be disregarded, which means that empathy is just as crucial. This does not imply that children who participate in philosophy for children workshops socialize with the intention of preserving the social order, but rather, that this is necessary as a form of social release, with the purpose of sharing emotional states, encouraging personal and social states and their transformation. Furthermore, empathy is a psychological phenomenon that relates human beings to their moral actions. Thus, philosophers Ann Gazzard and Claire Cassidy believe that practicing practical philosophy, such as philosophy with children, will lead to a better life, which also includes respecting human rights and the formation of a cohesive society (Cassidy, 2016).

The mind i.e., the cognitive, cannot be separated from someone's actions, regardless of their position in society. Scherz suggest that philosophy with children could be a bridge between theory, those moral laws within us, and the lived experiences, which is important, since philosophy is not separate from human beings and their moral codes. However, it is not enough for children to engage in moral considerations; instead, there needs to exist a structure in the form of a curriculum used by the teachers. Within this curriculum, it is important to establish a dialogical framework in which the children can join in the discussion on a great number of their own and the ideas of others, before they decide which direction their thoughts and actions will take. Thus, this is a cyclic direction, constantly shifting under the influence of new ideas and does not consist simply of reaching conclusions and remaining in a fixed place. This coincides with Veugelers's ideas that democracy also needs to be a social organization that the citizens must always re-examine. The aim of the very concept of philosophy with children is to raise people who are going to advance democracy, whose thought processes will be flexible and responsible, and who will not be susceptible to conformity and prevailing attitudes. Even the very instance of children meeting other children at philosophy with children workshops is an opportunity for them to practice democracy by joint contemplation (Cassidy, 2016).

\section{EXAMPLES OF PHILOSOPHY WITH CHILDREN WORKSHOPS ON THE TOPIC OF HUMAN RIGHTS}

In continuation, the paper presents two workshops intended for children aged 8-11, which employ the methods of philosophy with children, with the aim of raising the awareness of the importance of respecting human rights to/work towards helping children at the age 8 11 realize the necessity of. 


\section{“HUMAN RIGHTS” (GENERAL) WORKSHOP}

The aim of this workshop is for the participants (children, pupils) to learn the concept of human/children's rights, critically reflect on human rights and learn some of the basic human rights. The workshop is intended for working with children aged 8-11. It is recommended that the number of pupils in the educational work group does not exceed 15 children and two facilitators. The duration of the workshop is approximately 90 minutes or two school lessons.

There are two imaginary children's characters (may be illustrated in PowerPoint or other presentation software), who guide us through this workshop. They are a boy, Filip, and a girl, Sonja. At the start of the workshop, in PowerPoint or similar digital presentation tool, they point to an empty table for a word association game. Each participant opens one filed, e.g. A3 or $\mathrm{C} 2$, until all the fields are opened and until the participants guess the solution of each column and the final solution. The final solution is the word "school." The completed table looks like this:

Table 1. Word association game for workshop „Human Rights “

\begin{tabular}{|c|c|c|}
\hline A & B & C \\
Desks & Person & Croatian \\
\hline Board & Example to others & Math \\
\hline Space & Teaches & Nature and society \\
\hline Classroom & Teacher & School subject \\
\hline \multicolumn{3}{|c|}{} \\
\hline
\end{tabular}

The word association game is basically a logical game of notions. Pupils/children open the fields and connect notions, looking for logical connections between them. Once all the fields have been revealed or once they guess the solution of a column, the facilitator should explain the connections between the notions. Sometimes these logical connections are harder to discern, while, in our example, they are quite simple. The final solution is the notion "school," which will help us to initiate a discussion about school. The facilitator needs to repeat and emphasize the connections between the notions within each column, as well as between the solutions of each column.

After the pupils have solved the game, animated characters Filip and Sonja, ask basic questions. First, they ask the participants whether they perceive school as a positive or a negative notion. As in most workshops, the teacher or workshop facilitator asks follow-up questions. Perhaps the children do not know what a negative notion means, so the teacher can follow up by asking whether they like going to school. Some of the children will respond that they do, while others will respond that they do not like school. Then the teacher will clarify that those who do not like school regard it as a negative notion, whereas those who like it, see it as a positive notion. Of course, the teacher will follow up by asking why they do (not) like school. Both those who do and those who do not like school will have to substantiate their replies. Once they have explained it well, the teacher will ask them to try to come up with an answer together about what the positive aspects of school are. What is the purpose of school? After some discussion, they will reach the conclusion that school provides pupils with different forms of knowledge and skills. The next question is about how the pupils can use these knowledge and skills. The unavoidable conclusion is that these are skills and knowledge that help human beings succeed in life. Of course, a slightly different conclusion may be reached, but the important thing is that the meaning is similar. After this new discussion, Sonja, the animated character asks: Why should a child not go to school? The teacher tries to direct the questions so that the pupils come up with an argument for why a child should not go to school. If they come up with such an argument, the teacher will attempt to disprove it with a counter- 
THEORETICAL AND PRACTICAL PROBLEMS AND DISCUSSIONS

TEORIJSKI I PRAKTIČNI PROBLEMI I RASPRAVE

argument. The teacher continues the presentation and Sonja, the animated character asks: "Do you think all the children in the world go to school?" The children will most likely claim that all children must go to school. Then the teacher will hand out photocopies of a letter written by José, a boy from Mozambique. Each pupil will read aloud one sentence until they have finished reading the letter. Hello my dear friends!

My name is José. I am 11 years old. I live in the African country of Mozambique. My country is located all the way in the south of Africa, and it looks out onto the Indian Ocean. More precisely, I live on a farm in the inland part of the country, near the town of Mabote. I like all the same things as the other children my age: playing, especially football, animals, nature, TV, spending time with my friends, and other things. I would like to see my friends more often, but unfortunately, I can't. Since my father died last year, as the oldest son in the house, I have to take care of my mother and my younger brothers and sisters. That is why I work hard at our little farm, where we grow corn and sell it on the market in the nearby town. I thought I could go to school and still work on the farm, but I realized school was taking up too much of my time and I had to give it up. That is why, since last spring, I no longer go to school. I am very sorry about that because I learned many things there, and more importantly, I made many friends. I would like to go back to school, but my family needs me and I can't abandon them. I hope that someday I will be able to go back to school, but until then, I hope that at least you, my dear friends, go to school regularly and that you are happy to attend your classes, because there are those of us who would like to be in your place.

Your friend José

If necessary, if the teacher assesses that the pupils did not comprehend the letter well, the pupils will read it one more time. After they have read the letter, through Filip and Sonja, the teachers ask questions (and of course, after each question encourage the discussion with follow-up questions):

- Who is the author of the letter? Where does he live?

- How are you similar to him and how are you different?

- Why does he not go to school?

- Do you think it is wise that he has left school to work?

- What would you do if you were in his place? What advice would you give him?

- Why is school good for children anyway? What can you learn at school?

- Can we say that all children should go to school?

- Can we say that all children have the right to go to school?

- What does it mean that they have the right?

- Who is supposed to make sure they have this right?

- Do children have any other rights apart from going to school, apart from getting an education?

- Are any other of José's rights broken? Do adults have any rights? What sort of rights do they have?

During the dialogue, the facilitator is recommended to use the method of Socratic dialogue or a similar method employed in advanced philosophy with children workshops. After the discussion, it is time for the children to take a break while playing an educational game, naturally related to the topic of the workshop which is human rights.

5 The letter was created for the purpose of the workshop by Zvjezdana Cah. 
The facilitators divide the children into pairs. It is advisable that they partner up with students who are not normally in the same group. Each pair will get a piece of paper in the shape of a triangle. On the paper, they need to write some rights they can think of, and underneath, why they think these rights are important. After they have finished writing, it is time for analysis, with each pair presenting their rights and listening to other pairs. This way, they are able to compare their ideas. In the end, their answers and reasons are posted on the school panel board, which creates the "circle of human rights."

After this little thinking game, the facilitators continue with the conversation about human rights and again engage the pupils/participants in the debate. The animated characters ask the questions, while the teachers provide follow-up questions as follows:

- Do you think we have forgotten to mention a human right you think is important?

- Do you understand how different people can see the same rights differently?

- Are the rights of all the people on the planet, in a way, similar?

- Do you think that most people strive for the same things? Why is that?

- Then, can we say that there are rights that are the same for all people, some universal rights?

After the discussion, the teacher will tell a short story about the Universal Declaration of Human Rights: "In 1948, following the hardships of World War II, the United Nations, a body that looks after the wellbeing of all people on earth, created the Universal Declaration of Human Rights, which we can look at briefly." (The facilitator shows the document of the Universal Declaration of Human Rights in PowerPoint or another presentation tool, briefly lists the ten most important rights and explains them). The teachers ask the pupils whether they understand all of these rights, and if not, explains and clarifies what each of the rights means. The debate once again continues using the following questions:

1. How do we get the rights that we have mentioned?

2. Should we accept that the other children and adults have the same rights as us? Should we encourage people to respect other people's human rights?

3. Do you think it is good to often think about this and talk to our friends about it?

In order to take a little break, but continue thinking about human rights, the teachers present a hat and tell each pupil to take out one piece of paper with one human right written on it. Each pupil has to try to connect this right to a character from literature, cartoon, film, comic book or famous person who could best personify this right. Then the pupils have to draw a comic strip consisting of one or two pictures in which they will present their right, without mentioning it aloud. In the end, everyone will individually explain their comic, while the others have to try to guess to which right it refers. Once the participants guess the right, the pupils, including the author of the drawing, will discuss why they have chosen a particular character, i.e., the person they used to present a particular human right.

At the very end of the workshop, Filip, the animated boy, and Sonja, the animated girl, say a few closing words. Filip: “Dear friends, this is the end of our meeting today. Don't forget that every person has certain rights!" Sonja: "Goodbye and I hope you have learned some things today. I hope to see you again and have another conversation about human rights."

\section{WORKSHOP: BREAKING HUMAN RIGHTS}

The aim of the second workshop is for the participants (children, pupils) to critically reflect on the notion of the violation of human rights, discover how they may be violated and to take a stand against human rights violations. Another objective is to learn that breaking 
THEORETICAL AND PRACTICAL PROBLEMS AND DISCUSSIONS

TEORIJSKI I PRAKTIČNI PROBLEMI I RASPRAVE

human rights may cause harm to other children and adults. The workshop is intended for children aged 8-11. The recommended size of the group is 10 to 15 children accompanied by two facilitators. The duration of the workshop is approximately 45 minutes.

The workshop is guided by two imaginary animated children's characters, and these are once again Filip and Sonja. In a PowerPoint presentation or another presentation tool, Filip displays a riddle the children need to solve. Riddles are often used as additional materials to stimulate the thought process.

"Riddles that are often rhythmic and fun, lead to abstract thought. After several initial riddles, the pupils have established a way of solving them, that is, the methodology of deciphering metaphors and descriptions in riddles that should not be taken literally. After the pupils comprehend the concept of a riddle, one of the pupils is told the solution and their task is to lead the rest of the group to the correct answer, without actually saying it. The pupil is able to do so by using descriptions, associations, questions, and even, pantomime. This awakens the pupil's resourcefulness, creativity and the ability to comprehend and explain abstractions and associations to others" (Ćurko and Kragić 2009: 307-308).

Filip presents a riddle to the children:

"We are many brothers, everybody knows us, but some like to spend time with us, while others run from us. We exist since the beginning of time, but people learned about us and accepted us only after great disasters and war. We protect everyone and are afraid of no one. We hope you will accept us and grow to love us. We are..."

The answer, of course, is human rights. If the pupils do not guess the answer, the facilitator calls on one of the pupils and tells them the answer to the riddle. With the help of only one notion, that pupil has to help their colleagues reach the answer. Once the pupils discover the answer, it is followed by a discussion using the method of Socratic dialogue or a similar method employed in sophisticated philosophy with children programmes. The initial questions asked by the animated characters are as follows:

- In your own words, how would you explain to a friend what human rights are?

- Do you think that they somehow oblige the people to respect them and that all the people really respect human rights? What if somebody does not want to? Should there be punishments for that? What kind?

These are only the primary questions for opening the debate, while the teachers should use follow-up questions to encourage the discussion. After a short but intense discussion, the teachers and the pupils read a well-known story together. Stories are employed in different ways in philosophy with children workshops. A story may be used at different points in the workshop, depending on the aim.

be included

"Depending on the topic and other methods used during the lesson, a story may

- at the beginning of the lesson - which can serve as a means of motivation from which children gradually discern the topic of the lesson;

- in the middle of the lesson - where it serves as a specific template for the topic that has already been introduced and as way to move forward with the topic until the end of the lesson;

- at the end of the lesson - as a conclusion of the topic of the lesson"

(Ćurko and Kragić 2008: 112).

Moreover, sometimes well-known stories are used, while sometimes stories that have been specifically prepared for a particular workshop, or less known stories from other cultural traditions are used. For this workshop, we shall choose a well-known story, Cinderella, with which most children will be familiar. This time, we will not retell the story, but rather read it 
very carefully, with each pupil reading a few sentences. It is recommended to use the original version of the Cinderella fairy tale or a professional translation, rather than any of the embellished animated or live-action versions.

The tale is indeed long, but reading need not be rushed since it is important for the pupils to concentrate on the story. Another reason for reading a story is to promote the activity of reading, but also, to read the original fairy tale. Nowadays children read increasingly less, while they are acquainted with Cinderella, as well as other well-known and less-known fairy tales, by means of successful or less successful live-action and animated adaptations that are often altered to the degree that they are unrecognizable. After carefully reading the story, the animated facilitators start the discussion by introducing 'lighter' questions.

The reading is followed by a discussion. Animated characters Filip and Sonja ask the participants some questions. The aim of the first few questions is to ascertain whether the pupils have understood the story. These are typical questions, such as:

- What is this fairy tale about?

- How would you describe Cinderella and how would you describe her sisters and stepmother?

After a brief discussion about these basic themes of the story, the questions move in the direction of the workshop topic:

- Are any of Cinderella's rights violated?

- Can you list which of her rights are violated?

Here, the pupils could provide unexpected answers, however, the follow-up questions should direct them towards identifying all of Cinderella's rights that are possible being breached.

- What would you do in her place? Would you humbly put up with it like Cinderella?

- How do children usually react when some of their basic human rights are violated?

- Can you think of a child whose rights are violated?

- Are some of your rights breached?

- Do you think that today there are adults whose human rights are violated the way Cinderella's were? Can you think of any examples?

- Do you think that people who do not respect human rights, or take away other people's rights are somehow punished? Why and how are they punished?

- If you were running a country, what would you do with those who do break human rights?

- Do you have any idea how you as a pupil could contribute to human rights being respected more?

After every question and the answers obtained, follow-up questions should be asked in order to direct the discussion. It is important to discuss the necessity of respecting human rights, but also, that every breach of human rights consequently hurts or upsets someone. In order to include a skandalon as well, the animated teachers ask children the following questions:

- Did the stepsisters get a chance for a fair trial? The doves blinded them; is that too harsh a punishment for their behaviour?

- What would be the appropriate punishment for Cinderella's stepsisters?

- What is a fair trial? Would that be one of the human rights?

Here it is important to stress that when we become emotional or overly excited, we often make decisions that breach someone else's human rights, which is why it is necessary to 
think carefully before making a serious move. In order to finish the discussion with a creative game, the participants receive a task to invent a story in which one or more human rights will be violated.

The story should end suddenly, or rather, it should be open-ended. The pupils can choose the rights that will be violated on their own, or, if they cannot think of any, they may receive cards with human and children's rights written on them as a prompt. These cards should be prepared beforehand. After they have written their short stories, they will read them aloud, while the others will try to invent an ending for each of the stories.

In addition, the authors need to say why they chose precisely this human right and why they have decided to illustrate its breach in a particular way. That will be a way for the pupils to exchange their ideas and thoughts about human rights, while this final exercise will allow them to demonstrate to what extent they have understood the importance of human rights. At the end of the workshop, Sonja and Filip will say goodbye to the participants. Filip: "Dear friends, I bid you farewell, as I go and leaf through the Universal Declaration of Human Rights." Sonja: "And then he will try to teach me about it, like I do not already know all that. And I am sure you have already learned so much. Until next time, goodbye!" Before closing the workshop, the teachers ask whether the pupils have any additional questions.

\section{CONCLUSION}

The final aim and purpose of any upbringing is to help children and young people evolve into mature, self-confident and responsible adults. This cannot be achieved at once, whereas a child gradually moves from being a person focused on themselves, to turning toward others, realizing that they are not the only ones in the world and that others have the right to their "place under the sun" too. Philosophy with children can be of great assistance in this endeavour. It can help broaden their horizons and assist them in developing their own opinions, to contemplate about their daily lives; it can encourage them to express their questions, seek answers to them, as well as help them express concerns about the values that are important to everyone. Philosophy with children fosters the use of language during the process of contemplation, which leads to clearer speaking and writing later on, and most importantly, the children learn at an early age the importance of teamwork, since they have to work together with other participants and the teachers to discover the answers to questions that trouble them. That is why the topic of human rights is an ideal topic within philosophy with children programmes and workshops. Philosophy with children problematizes the concerns that occupy ordinary human beings in their daily life. Every person has human rights, which is why children, as future adult citizens, need to receive guidance for living in a democratic society.

In the democratic world, human rights are indeed a topic that has become a focus of the scientific community and the general public during the last 80 years. There have been numerous programmes and curricula for human rights within educational systems. These programmes employed different methods with the aim of making children aware of the necessity of preserving and respecting human rights. In today's digital world, as children read increasingly less, as immeasurable quantities of different information is available to them, i.e. two clicks away, there is a growing necessity for a more contemporary approach to classroom education. One of such different approaches is the development of philosophy with children. The approach has developed different methodologies adapted to today's age. However, many of the traditional methods and approaches to teaching still need to be preserved. More than ever before, it is vital to stress the importance of reading, both for children and for the adults. It is necessary to use today's digital technologies in traditional ways and to conceive functional classroom methods. Equally, in today's classroom, in the framework of both formal and informal education, it is an imperative to stress specific topics, one of which is the topic of human 
rights. Therefore, it has been interesting to see how human rights may be taught through of methods of philosophy with children, both in theoretical and practical sense. That is why this paper also includes the blueprints of two workshops that demonstrate one of the possible methodologies for working with human rights in philosophy with children. The first workshop employs a word associations game, a letter, a "circle of human rights", Socratic dialogue and a comic strip, to encourage the children to learn and ponder more deeply about the very notion and idea of human rights and to learn some of them. The second workshop begins with a riddle, but the basis for contemplation, i.e., the stimulus is the original tale of Cinderella. The final activity consists of inventing endings to the children's stories. The principal aim is to familiarize the children with the notion of the violation of human rights and to encourage them to promote the upholding of human rights themselves.

\section{REFERENCES}

Anđelić, N. (2008). Kratka povijest ljudskih prava, Sarajevo: ACIPS i Helsinški komitet za ljudska prava u Bosni i Hercegovini.

Becker, W. (2009). Ljudska prava: prilog analizi jednoga pojma. Politička misao : časopis za politologiju, 46(3), 205-216. Retrieved from https://hrcak.srce.hr/50952

Cassidy, C. (2016). Promoting human rights through Philosophy with children. International Journal of Childrens Rights, 24(3), 499-521.

Curko, B. (2020). Community of philosophical inquiry as a method in early bioethical education. JAHR - Europski časopis za bioetiku, 11(2), 481-497.

Ćurko, B., Feiner, F., Gerjolj, S. et al., (2015). Etičko obrazovanje i učenje o vrijednostima: priručnik za učitelje i odgajatelje. Lubljana: Ethika.

Ćurko, B. \& Kragić, I. (2008). Filozofija za djecu - primjer „Male filozofije“. Život i škola, 56(2), 61-68. Retrieved from https://hrcak.srce.hr/36899

Ćurko, B. \& Kragić, I. (2008). Upotreba priča u radionicama filozofije za djecu. Acta ladertina 5(1). Retrieved from https://hrcak.srce.hr/190063

Ćurko, B. \& Kragić, I. (2009). Igra-put k multidimenziranom mišljenju. Na tragu filozogije za djecu. Filozofska istraživanja 29(2), 303-310. Retrieved from https://hrcak.srce.hr/41409

Dewey, J. (1909). How We Think. New York: D. C Heath \& Co.

Kutleša, S. (Ed.), (2012). Filozofski leksikon. Zagreb: Leksikografski zavod Miroslav Krleža.

Grimm, J. \& Grimm, W. (2012). Bajke. Zagreb: Školska knjiga.

Hollós, R. (1989). Ljudska prava-bliska stvarnost ili bliska nedosežnost. Revija za sociologiju 20(3-4), 363-382. Retrieved from https://hrcak.srce.hr/155435

Jeremić, M. (2012). „Filozofija s djecom“ i motiviranje djece na učenje. Metodički ogledi 19(2), 79 87. Retrieved from https://hrcak.srce.hr/103687

Lipman, M. (2008). A Life Teaching Thinking. New Jersey: Institute for the Advancement of Philosophy for Children.

Radovan Burja, M. (2017). Filozofija odgoja i odgojna uloga pričanja priča o kršenju ljudskih prava. Metodički ogledi 24(2), 9-21. Retrieved from https://hrcak.srce.hr/199981

Shields, P. (2003). The Community of Inquiry. Administration \& Society 35(5), 510-538.

Šimenc, M. (2012). Dijalog u filozofiji s djecom i razvoj filozofije s djecom. Metodički ogledi 19(2), 13-27. Retrieved from https://hrcak.srce.hr/103677

Upbringing (2020). Hrvatska enciklopedija, mrežno izdanje. Leksikografski zavod Miroslav Krleža, 2020. Retrieved from http://www.enciklopedija.hr/Natuknica.aspx?ID=44727

Williams, S. (2012). A brief history of P4C, especially in the UK. In: Lizzy Lewis \&Nick Chandley (Eds), Philosophy for Children Through the Secondary Curriculum. London: Continuum Publishing group.

Williams, S. (n.d.). P4C: what, why and how? Retrieved from https://p4c.com/about-p4c/ 